\title{
Accessory corpora lutea formation in pregnant Hokkaido sika deer (Cervus nippon yesoensis) investigated by examination of ovarian dynamics and steroid hormone concentrations
}

\author{
Yojiro YANAGAWA ${ }^{1)}$, Yukiko MATSUURA ${ }^{2)}$, Masatsugu SUZUKI ${ }^{3)}$, Shin-ichi SAGA ${ }^{4}$, \\ Hideto OKUYAMA ${ }^{4)}$, Daisuke FUKUI ${ }^{4)}$, Gen BANDO ${ }^{4)}$, Masashi NAGANO ${ }^{1)}$, Seiji KATAGIRI5), \\ Yoshiyuki TAKAHASHI ${ }^{1)}$ and Toshio TSUBOTA ${ }^{6}$ \\ 1) Laboratory of Theriogenology, Graduate School of Veterinary Medicine, Hokkaido University, Hokkaido 060-0818, Japan \\ ${ }^{2)}$ Hokkaido Research Center Forestry and Forest Products Research Institute, Hokkaido 062-8516, Japan \\ 3) Laboratory of Zoo and Wildlife Medicine, Department of Veterinary Medicine, Faculty of Applied Biological Sciences, \\ Gifu University, Gifu 501-1193, Japan \\ 4) Asahiyama Zoological Park, Hoakkaido 078-8205, Japan. \\ 5) Department of Large Animal Clinical Science, School of Veterinary Medicine, Rakuno Gakuen University, Hokkaido \\ 069-8501, Japan \\ 6) Laboratory of Wildlife Biology, Graduate School of Veterinary Medicine, Hokkaido University, Hokkaido 060-0818, Japan
}

\begin{abstract}
Generally, sika deer conceive a single fetus, but approximately $80 \%$ of pregnant females have two corpora lutea (CLs). The function of the accessory CL (ACL) is unknown; moreover, the process of ACL formation is unclear, and understanding this is necessary to know its role. To elucidate the process of ACL formation, the ovarian dynamics of six adult Hokkaido sika deer females were examined ultrasonographically together with peripheral estradiol-17 $\beta$ and progesterone concentrations. ACLs formed in three females that conceived at the first estrus of the breeding season, but not in those females that conceived at the second estrus. After copulation, postconception ovulation of the dominant follicle of the first wave is induced by an increase in estradiol-17 $\beta$, which leads to formation of an ACL. A relatively low concentration of progesterone after the first estrus of the breeding season is considered to be responsible for the increase in estradiol-17 $\beta$ after copulation.
\end{abstract} Key words: Accessory corpus luteum, Estradiol, Follicular wave, Progesterone, Sika deer

(J. Reprod. Dev. 61: 61-66, 2015)

$\mathbf{S}^{\mathrm{i}}$ ka deer (Cervus nippon) are short-day breeders, mating in autumn and fawning in early summer [1]. Although they usually produce a single fawn, two corpora lutea (CLs) are found in about $80 \%$ of pregnant females [2]. The two CLs exist from early pregnancy and are maintained throughout the gestation period in sika deer, and the smaller CL is called the accessory CL (ACL) in cervid species [3]. There is no difference between the CLs in terms of histology [4] and ability to produce steroid hormones, as assessed immunohistochemically for steroidogenic enzymes [5]. Since not all pregnant females have an ACL, an ACL is not essential for maintaining pregnancy. Thus, the function of the ACL is not clear. Elucidation of the reproductive difference between females with and without an ACL would provide valuable information for understanding the reproductive status of females. ACLs are also found in other cervid species, such as the red deer (Cervus elaphus) [3, 6-8], wapiti (Cervus canadensis) [9], and reindeer (Rangifer tarandus) $[10,11]$. ACLs in deer are assumed to

Received: June 12, 2014

Accepted: October 29, 2014

Published online in J-STAGE: December 6, 2014

(C2015 by the Society for Reproduction and Development

Correspondence: Y Yanagawa (e-mail: yoji-y@vetmed.hokudai.ac.jp)

This is an open-access article distributed under the terms of the Creative Commons Attribution Non-Commercial No Derivatives (by-nc-nd) License $<$ http://creativecommons.org/licenses/by-nc-nd/3.0/>. be derived from postconception ovulation $[7,9]$ or a retained CL of a previous ovulation $[8,12,13]$. However, these hypotheses are based on observation of ovaries from carcasses. The origin and process of ACL formation in cervid species have never been confirmed, and this is necessary to understand the function of the ACL.

ACLs in pregnant females can also be found in other mammal species, and they form in various manners. ACLs in pregnant mares are derived from postconception ovulation or luteinization of anovulatory follicles after conception [14]. On the other hand, ACLs in pregnant elephants result from luteinization of the dominant follicle in the anovulatory wave emerging prior to the ovulatory wave at estrus [15-17]. Moreover, double ovulations sometimes occur in cattle [18] and horses [19], which results in two CLs. These findings were clarified by studying follicular and luteal dynamics (ovarian dynamics) using ultrasonography together with steroid hormone dynamics in live animals.

The ovarian dynamics in sika deer have never been investigated. In other cervid species, the wapiti and red deer, ovarian dynamics have been investigated by ultrasonography [20-23], but these studies were only performed in nonpregnant animals, and therefore, ACL formation could not be observed. The purpose of the present study was to clarify the process of ACL formation in pregnant sika deer by investigating ovarian and hormonal dynamics. 


\section{Materials and Methods}

Six mature female (female A-F) Hokkaido sika deer (Cervus nippon yesoensis) were kept in a pen of about $80 \mathrm{~m}^{2}$ with a stag and examined between September 20, 2007, and January 17, 2008, at Asahiyama Zoological Park, Hokkaido, Japan. Three of them (females A, B and F) were multiparous females over 3 years old that weighed $81.3 \pm 2.1 \mathrm{~kg}$ (mean $\pm \mathrm{SD}$ ) and had suckling fawn until August. The others (females C, D and E) were nulliparous 1-year-old females that weighed $67.0 \pm 1.3 \mathrm{~kg}$. The ages of the animals were estimated by tooth replacement [24]. About $1 \mathrm{~kg}$ of concentrated feed was supplied daily per animal, with hay and water ad libitum. Behaviors of the animals were observed for estrus and copulation visually or by video recording all day long. Estrus was defined as a female permitting the mounting of a male. Also, chasing, licking, sniffing, touching and placing the chin on the back were considered as estrous symptoms. The present study was conducted in accordance with the Hokkaido University guidelines for the care and use of laboratory animals.

The animals were immobilized for examination by intramuscular administration of a mixture containing medetomidine- $\mathrm{HCl}(60 \mu \mathrm{g} / \mathrm{kg}$; Domitor, Zenoaq Nippon Zenyaku Kogyo, Fukushima, Japan) and ketamine-HCl (3 mg/kg; Ketalar, Sankyo, Tokyo, Japan) using a blow dart. After examination, they were awakened with an intramuscular administration of atipamezole- $\mathrm{HCl}(150 \mu \mathrm{g} / \mathrm{kg}$; Antisedan, Zenoaq Nippon Zenyaku Kogyo).

Females were examined at two- or three-day intervals, except for one female that was examined at five- or six-day intervals until December 15, 2007 (female F). Following immobilization, the females were laid in lateral recumbency, and the feces were removed from the rectum manually prior to examination. The ovaries and uteri were examined using ultrasonography (HS-1500V, Honda Electronics, Aichi, Japan) by insertion into the rectum of a linear transducer (10 MHz, HLV-375M, Honda Electronics, Aichi, Japan) attached to a rigid plastic pipe extender (length, $60 \mathrm{~cm}$; diameter, $3.5 \mathrm{~cm}$ ). The transducer was covered with rubber cover filled with conductivity gel, and conductivity gel was also infused into the rectum before transducer insertion. Detailed drawings of the ovaries were made to record the diameter and relative position of follicles and the CLs. The drawings were used to tabulate follicles $\geq 3 \mathrm{~mm}$ in diameter within the pair of ovaries of each female for each day of the examination and to construct diameter profiles of uniquely identified follicles from their first appearance at $3 \mathrm{~mm}$ in diameter, due to $3 \mathrm{~mm}$ being the minimum size observable by ultrasonography, until they could no longer be uniquely identified (regressed to $\leq 3 \mathrm{~mm}$ ). A follicular wave was defined as the synchronous growth of a group of small follicles, and the dominant follicle was defined as a follicle that attained a diameter $\geq 7 \mathrm{~mm}$ and exceeded the diameter of all others, as the diameter of the ovulated follicle 1-2 days before ovulation was at least $7 \mathrm{~mm}$. Ovulation was defined as the disappearance of the dominant follicle identified during the previous examination, and was confirmed by detection of a CL at the same location afterward. Pregnancies were confirmed by the presence of fetuses with a heartbeat, which could be detected on day 20 of pregnancy at the earliest [25]. Plasma samples were collected by jugular venipuncture (EDTA-loaded vacuum tubes) at each examination and stored at
$-20 \mathrm{C}$ until assayed. A pair of ovaries was collected from a female that died in an accident during transportation after the study period.

The plasma concentrations of estradiol- $17 \beta$ and progesterone were determined using competitive double-antibody enzyme immunoassays. For the estradiol-17 $\beta$ assay, $2 \mathrm{ml}$ of plasma was extracted with $6 \mathrm{ml}$ of diethyl ether. Then the diethyl ether was decanted into a new tube after freezing the plasma. After evaporating the diethyl ether, 0.5 $\mathrm{ml}$ of acetonitrile and $1 \mathrm{ml}$ of hexane were added and mixed well. Thereafter, $1 \mathrm{ml}$ of hexane was added again, and all the hexane was discarded using an aspirator. The acetonitrile was evaporated after repeating delipidation by hexane thrice. Samples were reconstituted with $100 \mu$ l of assay buffer ( $145 \mathrm{mM} \mathrm{NaCl}, 40 \mathrm{mM} \mathrm{Na}_{2} \mathrm{HPO}_{4}, 0.1 \%$ $\mathrm{BSA}(\mathrm{w} / \mathrm{v}), \mathrm{pH}$ 7.2). For the progesterone assay, $200 \mu \mathrm{l}$ of plasma were extracted with $2 \mathrm{ml}$ of diethyl ether, and reconstituted with $200 \mu \mathrm{l}$ of assay buffer without delipidation using acetonitrile and hexane. Twenty microliters of samples were incubated for $16-18 \mathrm{~h}$ at $4 \mathrm{C}$ with the primary antisera and HRP-labeled hormone, $100 \mu \mathrm{l}$ each, in the well of a 96-well microplate (Costar 3590, Corning, NY, USA) coated with the secondary antiserum. After washing all the wells for 4 times with $300 \mu$ of washing buffer $(0.05 \%$ Tween 80$)$, $150 \mu \mathrm{l}$ of TMB solution ( $5 \mathrm{mM}$ citric acid, $50 \mathrm{mM} \mathrm{Na}_{2} \mathrm{HPO}_{4}, 500$ mM UHP, $1 \mathrm{mM} \mathrm{TMB}$ and 2\% DMSO) was added to each well and incubated for $40 \mathrm{~min}$ at $37 \mathrm{C}$. Absorbance of the solution in the wells was read by a microplate reader (Model 550, Bio-Rad Laboratories, Tokyo, Japan) set to $450 \mathrm{~nm}$ after stopping the chromogenic reaction with $50 \mu \mathrm{l}$ of $4 \mathrm{~N} \mathrm{H}_{2} \mathrm{SO}_{4}$. The primary antisera used for assay of estradiol-17 $\beta$ and progesterone were anti-estradiol-17 $\beta-6-C M O-B S A$ $[26,27]$ and anti-progesterone-3-CMO-BSA (7720-0504, Biogenesis, Poole, England). The antiserum against estradiol- $17 \beta$ cross-reacted with estrone (1.0\%), estradiol-17 $\beta$ (1.0\%), and estradiol-3-benzoate $(50.0 \%)$. The antiserum against progesterone cross-reacted only with pregnenolone (20.0\%). Goat anti-rabbit serum (270335, Seikagaku, Tokyo, Japan) was used as the secondary antiserum. All samples were assayed in triplicate. The assay sensitivities were $4.2 \mathrm{pg} / \mathrm{well}$ for estradiol-17 $\beta$ and $4.3 \mathrm{pg} /$ well for progesterone. The intra- and inter-assay coefficients of variation were 3.5 and $12.7 \%$ for estradiol$17 \beta$ and 3.2 and $6.8 \%$ for progesterone, respectively.

The plasma progesterone concentrations on the day that a dominant follicle was last observed before postconception ovulation in females that formed an ACL and on the day that a dominant follicle of the first wave emerged after the first and second copulations reached its maximum size in females that did not form an ACL were compared by one-way ANOVA followed by Tukey-Kramer's HSD as a post hoc test. Data are shown as the mean $\pm \mathrm{SD}$. All analyses were performed using a JMP Pro (version 10.0.0, SAS Institute, Cary, NC, USA).

\section{Results}

In three females (Group 1: A, B and C), at the first estrus of the breeding season, the dominant follicle of the first wave that emerged after copulation ovulated in the presence of the CL of pregnancy, and an ACL formed after postconception ovulation (Figs. 1 and 2). Postconception ovulations (disappearance of the dominant follicle) were confirmed between 8-20 days after copulation (Fig. 1). There was no return of estrus in the three females, and pregnancies were confirmed by $26-29$ days after copulation. 


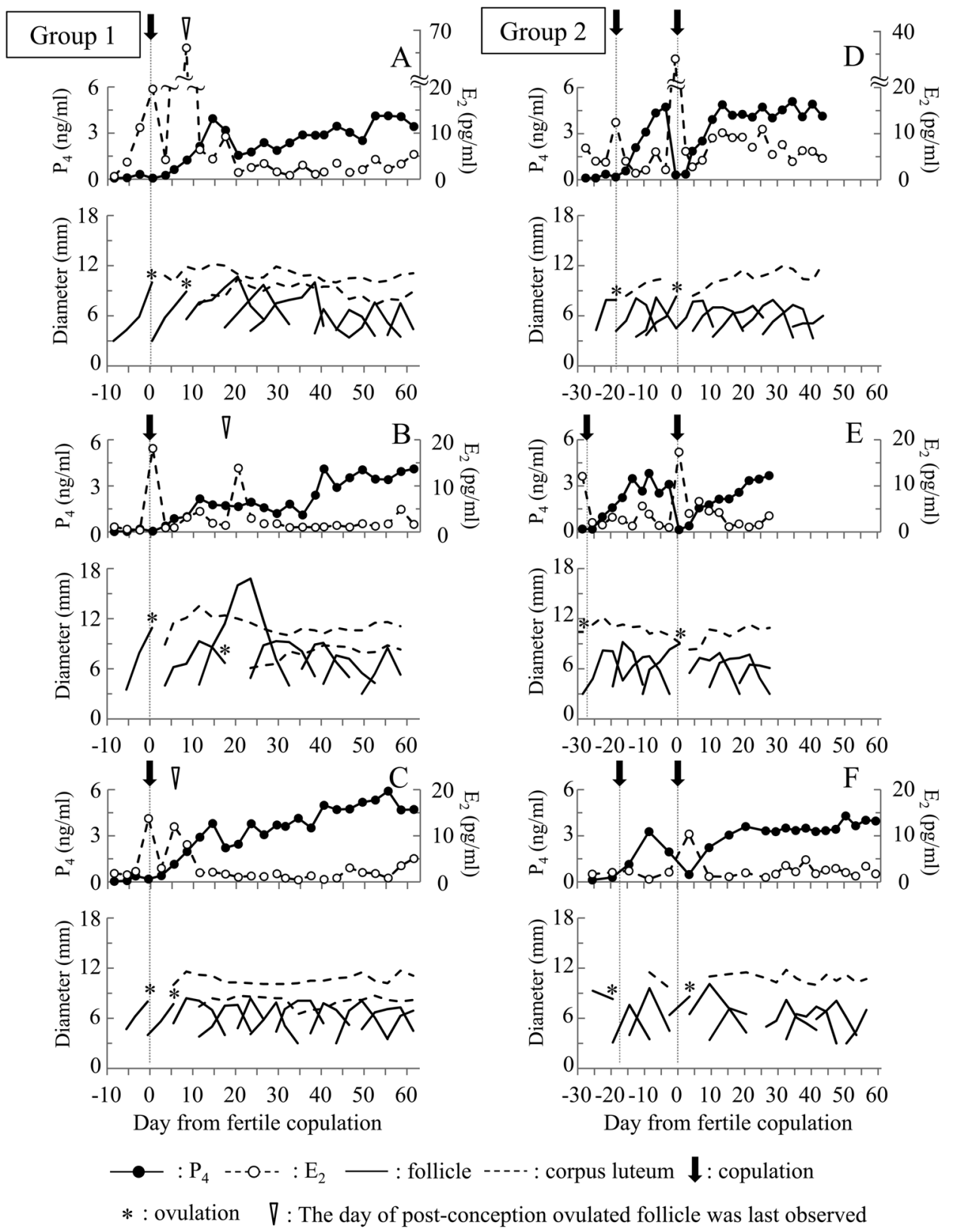

Fig. 1. Hormonal and ovarian dynamics in female sika deer that conceived at the first estrus (Group 1: A, B and C) and second estrus (Group 2: D, E and F) of the breeding season. $\mathrm{P}_{4}$ : progesterone. $\mathrm{E}_{2}$ : estradiol-17 $\beta$.

In the other three females (Group 2: D, E and F), estrus returned 18-28 days after copulation at the first estrus of the breeding season, and the females copulated again. The CL that formed at the first estrus regressed before the second estrus (Fig. 1). Pregnancies were confirmed by 20-27 days after the second copulation, and one CL was observed until the end of the study period.

In two females of Group 1 (females A and C), postconception ovulation was observed before detecting the diameter of the dominant follicle starting to retrocede by observation at the intervals used in the present study. On the other hand, the dominant follicle of the first wave ovulated after detecting that the size had started to decrease in the female B. The dominant follicle of the second wave did not ovulate even though it was bigger at the time of postconception ovulation and reached as big as $16.8 \mathrm{~mm}$ in female B (Fig. 1). Around the time of postconception ovulation, an increase in plasma estradiol-17 $\beta$ concentrations was observed in all females of Group 1 (30.6 \pm 30.7 $\mathrm{pg} / \mathrm{ml}$ : Table 1). However, there were no estrous symptoms, estrous behavior, or stag interest observed around the days of postconception ovulation. On the other hand, the estradiol-17 $\beta$ concentrations in Group 2 did not exceed $10 \mathrm{pg} / \mathrm{ml}$ after fertile copulation (Fig. 1). 

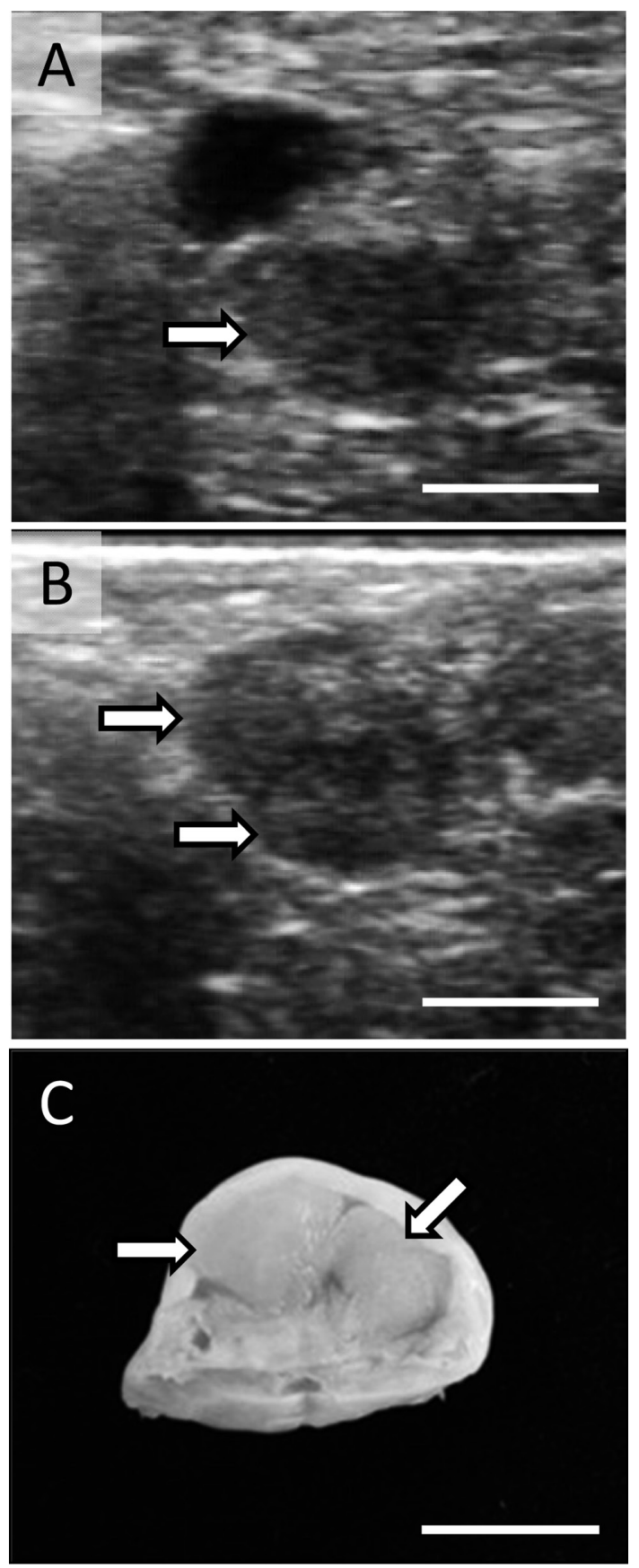

Fig. 2. Ultrasonographic and macroscopical images of an ovary in female sika deer A. (A) Ultrasonographic image of an ovary with a corpus luteum (CL) and dominant follicle of the first wave on day 8 of pregnancy. (B) Ultrasonographic image of the same ovary with two CLs on day 11 of pregnancy. (C) Macroscopical images of an ovary with two CLs on day 85 of pregnancy obtained after accidental death. Arrows indicate a CL. Bar $=1 \mathrm{~cm}$

The concentrations of progesterone just before the time of postconception ovulation in Group $1(1.4 \pm 0.3 \mathrm{ng} / \mathrm{ml}$, Table 2) were significantly lower than that on the day when the dominant follicle of the first wave that emerged after the second copulation attained its
Table 1. Estradiol-17 $\left(\mathrm{E}_{2}\right)$ concentrations of female sika deer in Group 1 (with an ACL)

\begin{tabular}{ccccc}
\hline Deer ID & $\begin{array}{c}\text { Days after } \\
\text { copulation* }\end{array}$ & $\begin{array}{c}\mathrm{E}_{2} \text { concentration } \\
(\mathrm{pg} / \mathrm{ml})\end{array}$ & & $\begin{array}{c}\text { Days postconception } \\
\text { ovulation confirmed }\end{array}$ \\
\cline { 1 - 3 } & 8 & 66.1 & & 11 \\
$\mathrm{~B}$ & 20 & 13.9 & & 20 \\
$\mathrm{C}$ & 5 & 12.0 & \\
\hline Mean $\pm \mathrm{SD}$ & & $30.6 \pm 30.7$ &
\end{tabular}

* The day of the $\mathrm{E}_{2}$ concentration peaked around postconception ovulation

maximum size in Group $2(2.3 \pm 0.2 \mathrm{ng} / \mathrm{ml}: \mathrm{P}<0.05)$. The plasma progesterone concentration at the time when the first dominant follicle reached its maximum size after the first copulation in Group $2(1.6 \pm 0.5 \mathrm{ng} / \mathrm{ml})$ did not differ from those of the other two periods described above but tended to be low compared with that after the second estrus in Group $2(\mathrm{P}=0.10$, Table 2$)$. After ACL formation, the progesterone concentration decreased and increased thereafter in females A and C. In female B, the progesterone concentration dynamics were similar to those of females $\mathrm{A}$ and $\mathrm{C}$ except that the progesterone concentration had already started to decrease before ACL formation. In Group 2, the progesterone concentration increased linearly to a plateau level (3.3-5.1 ng/ml) after copulation (Fig. 1).

All females delivered a healthy fawn normally except female A, which died on day 85 of pregnancy during transportation to another institution after the examination period. In the left ovary of female A, two CLs similar to those observed in ultrasonographic images were confirmed (Fig. 2C).

\section{Discussion}

In present study, ACLs formed only in females that conceived at the first estrus of the breeding season in the sika deer. This may be due to the low progesterone concentrations in the females in Group 1 at the time of postconception ovulation compared with the progesterone level at the time that the first dominant follicle after fertile copulation (at the second estrus) reached an ovulatory size in Group 2. It is known that progesterone has a negative feedback effect on LH secretion [28]. Therefore, a low level of progesterone could not suppress the increase in LH pulse frequency that leads to an estradiol-17 $\beta$ surge, which was observed in Group 1, and probably a subsequent LH surge. In a previous study, the presence of an increase in estrogen and the effect of estrogen after conception in pregnant females with an ACL were already predicted based on the prolonged existence of the estrogen receptor in the uteri of pregnant sika deer with an ACL [29]. Even though there was no significant difference in the progesterone concentrations at the time of postconception ovulation period in Group 1 and the first dominant follicle after unfertile copulation (at the first estrus) reached the ovulatory size in Group 2, ovulation of the first dominant follicle after the first copulation did not occurr in Group 2. The reason for this inconsistency is not clear, but the variation in follicular response to gonadotropin was also reported in ewes [30], which was suggested to be due to difference in intraovarian regulatory mechanisms, such as gonadotropin receptor populations [31]. For further discussion, 
Table 2. Progesterone $\left(\mathrm{P}_{4}\right)$ concentrations of female sika deer in Groups 1 (with an ACL) and 2 (without an ACL) at certain days after copulation

\begin{tabular}{|c|c|c|c|c|c|c|c|}
\hline \multicolumn{3}{|c|}{ Group 1} & \multicolumn{5}{|c|}{ Group 2} \\
\hline Deer ID & $\begin{array}{l}\text { Days after } \\
\text { copulation* }\end{array}$ & $\begin{array}{c}\mathrm{P}_{4} \text { concentration } \\
(\mathrm{ng} / \mathrm{ml})\end{array}$ & Deer ID & $\begin{array}{l}\text { Days after } \\
\text { copulation** }\end{array}$ & $\begin{array}{l}\mathrm{P}_{4} \text { concentration }(\mathrm{ng} / \mathrm{ml}) \\
\text { after } 1 \text { st copulation }\end{array}$ & $\begin{array}{c}\text { Days after } \\
\text { copulation*** }\end{array}$ & $\begin{array}{l}\mathrm{P}_{4} \text { concentration }(\mathrm{ng} / \mathrm{ml}) \\
\text { after } 2 \text { nd copulation }\end{array}$ \\
\hline A & 8 & 1.25 & D & 8 & 1.58 & 12 & 2.14 \\
\hline B & 17 & 1.72 & E & 6 & 2.09 & 7 & 2.52 \\
\hline $\mathrm{C}$ & 5 & 1.15 & $\mathrm{~F}$ & 3 & 1.15 & 9 & 2.24 \\
\hline \multicolumn{2}{|c|}{ Mean \pm SD } & $1.4 \pm 0.3^{\mathrm{a}}$ & & & $1.6 \pm 0.5^{\mathrm{ab}}$ & & $2.3 \pm 0.2^{b}$ \\
\hline
\end{tabular}

* The last day of the first dominant follicle observed before postconception ovulation. ** The day when the first dominant follicle reached its maximum size. ${ }^{\mathrm{a}, \mathrm{b}}$ Values with different superscripts differ significantly within a row $(\mathrm{P}<0.05)$.

more detailed and precise hormonal research, including research pertaining to gonadotropin, and research of follicular conditions are needed. In female $\mathrm{B}$, the dominant follicle of the first wave ovulated after decreasing in diameter, and the dominant follicle of the second wave did not ovulate even though it was bigger than the dominant follicle of the first wave. The mean maximum follicular size in the cyclic cervid was reported to not exceed $12 \mathrm{~mm}[20,22]$, and the same trend was observed in other follicles in the present study. Therefore, the dominant follicle of the second wave in female $\mathrm{B}$ in the present study can be considered as a cystic follicle, and it may have had an abnormality in response to LH. Also, because it is known that there is hypothalamus-pituitary function disorder in cows with a cystic follicle [32], abnormality in LH secretion may have delayed the timing of the ovulation of first dominant follicle in female B. However, there is no previous report about cystic follicles in cervid species, and more cases and information needs to be gathered for further discussion.

In Group 1, the progesterone concentration decreased once or did not increase much after copulation. In ewes, it is known that luteal function at the first estrus of the season is insufficient compared with that during the mid-breeding season [33]. Therefore, similar to the case in ewes, CL function at the first estrus of the season in sika deer may also be insufficient. However, even though the progesterone concentration was relatively low after the first estrus in the female of Group 2, it increased linearly thereafter and reached as high as the peak level of cyclic cervid species previously reported [22,34]. The reason for this inconsistency between the two groups is not clear, but one possibility is the presence of an increase in estradiol-17 $\beta$. Estradiol reportedly triggers the release of hypophysial oxytocin, and this stimulates release of a small quantity of uterine prostaglandin $\mathrm{F}_{2 \alpha}$, which leads to luteolysis [35]. The reason why the CL of pregnancy did not regress completely is unclear, but it might be supported by interferon tau, which is known as the factor of maternal recognition of pregnancy and is also found in cervid species [36], since it is involved in regulation of luteolysis [37].

The progesterone concentrations did not increase soon after ACL formation. This might be due to a low ability to produce progesterone in the ACL during the early pregnancy period because it is reported that $3 \beta$-hydroxysteroid dehydrogenase, the steroidogenic enzyme that synthesizes progesterone, could be detected only in luteal cells located in the peripheral region of the ACL until it was fully developed in mid-pregnancy [5]. Even though the ACL has a low ability to produce progesterone in early development, it can be an additive or assured source of progesterone in the case that the function of the CL of pregnancy is decreased, and it may be able to help to maintain the progesterone level required for maintenance of pregnancy by supporting the CL of pregnancy. In further studies, detailed examinations and analyses using more animals are needed to confirm the present speculations.

Interestingly, about $80 \%$ of the female sika deer conceived at the first estrus of the breeding season [38], and this number is consistent with the rate of ACLs found in the wild population [2]. This consistency supports the present results showing that only females that conceived at the first estrus formed an ACL and suggests that the timing of conception is related to ACL formation. Moreover, pregnant females with an ACL have heavier fetuses than pregnant females without an ACL in those harvested from the same population during the same period [2], which indicates that females with an ACL conceived relatively earlier. The ecological advantage of ACL formation is that it enables females to conceive early in the breeding season, as delayed conception leads to delayed parturition [39], which negatively influences fawn survivability [40] and fertility of the females in the subsequent breeding season [41] .

The present study showed the process of ACL formation in pregnant sika deer and that the origin of the ACL is postconception ovulation, which may occur due to a relatively low ability to produce progesterone in the CL during the first estrous cycle of the breeding season. Since LH support the CL ability and also destine follicle to ovulate, measurement of LH is necessary for further study.

\section{Acknowledgements}

We thank Dr H Igota, Mr J Igota, Mr A Ohsawa, and Mr S Nakahara for providing captive deer and helping with transportation. We are also indebted to Dr M Matsui for his advice on ultrasonographic examination. We would like to thank Dr A Miyamoto for providing the estradiol-17 $\beta$ antibody. This work was supported by the Inui Memorial Trust for Research on Animal Science.

\section{References}

1. Suzuki M, Kaji K, Yamanaka M, Ohtaishi N. Gestational age determination, variation of conception date, and external fetal development of sika deer (Cervus nippon yesoensis Heude, 1884) in eastern Hokkaido. J Vet Med Sci 1996; 58: 505-509. [Medline] [CrossRef]

2. Suzuki M, Koizumi T, Kobayashi M. Reproductive characteristics and occurrence of accessory corpora lutea in sika deer Cervus nippon centralis in Hyogo prefecture, Japan. $J$ 
Mammal Soc Jpn 1992; 17: 11-18.

3. Kelly RW, Challies CN. Incidence of ovulation before the onset of the rut and during pregnancy in red deer hinds. NZ J Zool 1978; 5: 817-819. [CrossRef]

4. Suzuki M. Reproductive characteristics and morphology of accessory corpora lutea in sika deer in Hokkaido. In: Ohtaishi N, Sheng H (eds.), Deer of China-Biology and Management-. Amsterdam: Elsevier; 1993: 356-363.

5. Matsuura Y, Suzuki M, Hayakawa D, Asano M, Sasaki M, Kitamura N, Yamada J, Tsubota T, Ohtaishi N. Immunohistochemical localization of steroidogenic enzymes in corpus luteum of wild sika deer during early mating season. Jpn J Vet Res 2004; 51: 167-172. [Medline]

6. Douglas MJW. Occurrence of accessory corpora lutea in red deer Cervus elaphus. J Mammal 1966; 47: 152-153. [CrossRef]

7. Guinness F, Lincoln GA, Short RV. The reproductive cycle of the female red deer, Cervus elaphus L. J Reprod Fertil 1971; 27: 427-438. [Medline] [CrossRef]

8. Kelly RW, McNatty KP, Moore GH. Hormonal changes about oestrus in female red deer. In: Fennessy PF, Drew KR (eds.), Biology of Deer Production. Wellington: The Royal Society; 1985: 181-184.

9. Halazon GC, Buechner HK. Postconception ovulation in elk. Trans North Am Wildl Nat Resour Conf 1956; 21: 545-554.

10. Dauphiné TC Jr. Morphology of the barren-ground caribou ovary. Can J Zool 1978; 56: 1684-1696. [Medline] [CrossRef]

11. Leader-Williams N, Rosser AM. Ovarian characteristics and reproductive performance of reindeer, Rangifer tarandus. J Reprod Fertil 1983; 67: 247-256. [Medline] [CrossRef]

12. Yamauchi S, Murai T, Nishitani Y. Studies on the ovary of the Japanese deer, Cervus nippon, in the Nara Park. -Postnatal development and seasonal changes. Jpn J Anim Reprod 1984; 30: 162-173. [CrossRef]

13. Suzuki M, Ohtaishi N. Reproduction of female sika deer (Cervus nippon yesoensis Heude, 1884) in Ashoro district, Hokkaido. J Vet Med Sci 1993; 55: 833-836. [Medline] [CrossRef]

14. Bergfelt DR, Adams GP. Luteal development. In: McKinnon AO, Squires EL, Aaala WE, Varner DD (eds.), Equine Reproduction. Philadelphia: Blackwell Publishing Ltd; 2011: 2055-2064.

15. Hermes R, Olson D, Goritz F, Brown JL, Schmitt DL, Hagan D, Peterson JS, Fritsch G, Hildebrandt TB. Ultrasonography of the estrous cycle in female African elephants (Loxodonta africana). Zoo Biol 2000; 19: 369-382. [CrossRef]

16. Lueders I, Niemuller C, Gray C, Rich P, Hildebrandt TB. Luteogenesis during the estrous cycle in Asian elephants (Elephas maximus). Reproduction 2010; 140: 777-786. [Medline] [CrossRef]

17. Hildebrandt TB, Lueders I, Hermes R, Goeritz F, Saragusty J. Reproductive cycle of the elephant. Anim Reprod Sci 2011; 124: 176-183. [Medline] [CrossRef]

18. Wiltbank MC, Fricke PM, Sangsritavong S, Sartori R, Ginther OJ. Mechanisms that prevent and produce double ovulations in dairy cattle. J Dairy Sci 2000; 83: 2998-3007. [Medline] [CrossRef]

19. Ginther OJ, Gastal EL, Gastal MO, Beg MA. Dynamics of the equine preovulatory follicle and periovulatory hormones: What's new? J Equine Vet Sci 2008; 28: 454-460. [CrossRef]

20. Asher GW, Scott IC, Mockett BG, O'Neill KT, Diverio S, Inskeep EK, Townsend EC. Ultrasonographic monitoring of ovarian function during the oestrous cycle of fallow deer (Dama dama). In: Zomborsky Z (ed.), Advances in Deer Biology. Proceedings of the 4th International Deer Biology Congress. Kaposvar, Hungary; 1999: 148-152.

21. McCorkell RB, MacDougall L, Adams GP. Ovarian follicle development in wapiti (Cervus elaphus) during the anovulatory season. Theriogenology 2004; 61: 473-483. [Medline] [CrossRef]

22. McCorkell R, Woodbury M, Adams GP. Ovarian follicular and luteal dynamics in wapiti during the estrous cycle. Theriogenology 2006; 65: 540-556. [Medline] [CrossRef]

23. McCorkell R, Woodbury MR, Adams GP. Ovarian follicular and luteal dynamics in wapiti during seasonal transitions. Theriogenology 2007; 67: 1224-1232. [Medline] [CrossRef]

24. Koike H, Ohtaishi N. Prehistoric hunting pressure estimated by the age composition of excavated sika deer (Cervus-nippon) using the annual layer of tooth cement. $J$ Archaeo Sci 1985; 12: 443-456. [CrossRef]

25. Yanagawa Y, Matsuura Y, Suzuki M, Saga S, Okuyama H, Fukui D, Bandou G, Katagiri S, Takahashi Y, Tsubota T. Fetal age estimation of Hokkaido sika deer (Cervus nippon yesoensis) using ultrasonography during early pregnancy. J Reprod Dev 2009; 55 143-148. [Medline] [CrossRef]

26. Meyer HH, Sauerwein H, Mutayoba BM. Immunoaffinity chromatography and biotin-streptavidin amplified enzymeimmunoassay for sensitive and specific estimation of estradiol-17 beta. $J$ Steroid Biochem 1990; 35: 263-269. [Medline] [CrossRef]

27. Braun J, Moriuchi Y, Nakagawa S, Hochi S, Miyamoto A, Oguri N. Follicular development, progesterone and estradiol-17beta levels during spontaneous and FSH-stimulated estrous cycles in Hokkaido native pony and thoroughbred mares. J Reprod Dev 1994; 40: 141-147. [CrossRef]

28. Stevenson JS. CHAPTER 35 - Clinical Reproductive Physiology of the Cow. In: Youngquist RS, Threlfall WR (eds.), Current Therapy in Large Animal Theriogenology (Second Edition). Saint Louis: W.B. Saunders; 2007: 258-270.

29. Yanagawa Y, Matsuura Y, Suzuki M, Katagiri S, Tsubota T. Immunohistochemical localization of the estrogen receptor alpha (ERalpha) and progesterone receptor (PR) in the uterus of sika deer (Cervus nippon) during pregnancy. Jpn J Vet Res 2008; 56: 139-149. [Medline]

30. Bartlewski PM, Beard AP, Chapman CL, Nelson ML, Palmer B, Aravindakshan J, Cook SJ, Rawlings NC. Ovarian responses in gonadotrophin-releasing hormone-treated anoestrous ewes: follicular and endocrine correlates with luteal outcome. Reprod Fertil Dev 2001; 13: 133-142. [Medline] [CrossRef]

31. Webb R, Gosden RG, Telfer EE, Moor RM. Factors affecting folliculogenesis in ruminants. Anim Sci 1999; 68: 257-284.

32. Vanholder T, Opsomer G, de Kruif A. Aetiology and pathogenesis of cystic ovarian follicles in dairy cattle: a review. Reprod Nutr Dev 2006; 46: 105-119. [Medline] [CrossRef]

33. Bartlewski PM, Beard AP, Rawlings NC. Ovarian function in ewes at the onset of the breeding season. Anim Reprod Sci 1999; 57: 67-88. [Medline] [CrossRef]

34. Liu BT, Cheng SP, Huang MC, Yu JYL. Serum progesterone changes in luteal cyclicity and duration of estrous cycle in Formosan sika deer (Cervus nippon taiouanus) hinds. Zoolog Sci 2002; 19: 1033-1037. [Medline] [CrossRef]

35. Niswender GD, Juengel JL, Silva PJ, Rollyson MK, McIntush EW. Mechanism controlling the function and life span of the corpus luteum. Physiol Rev 2000; 80: 1-29. [Medline]

36. Demmers KJ, Jabbour HN, Deakin DW, Flint APF. Production of interferon by red deer (Cervus elaphus) conceptuses and the effects of roIFN-tau on the timing of luteolysis and the success of asynchronous embryo transfer. J Reprod Fertil 2000; 118: 387-395. [Medline] [CrossRef]

37. Spencer TE, Becker WC, George P, Mirando MA, Ogle TF, Bazer FW. Ovine interferon-tau inhibits estrogen receptor up-regulation and estrogen-induced luteolysis in cyclic ewes. Endocrinology 1995; 136: 4932-4944. [Medline]

38. Matsuura Y, Sasamoto Y, Sato K, Takahashi Y, Suzuki M, Ohtaishi N. Monitoring ovarian cycle and conception by fecal progesterone analysis in sika deer. Ecol Res 2004; 19: 397-404. [CrossRef]

39. Matsuura Y, Sato K, Suzuki M, Ohtaishi N. The effects of age, body weight and reproductive status on conception dates and gestation periods in captive sika deer. Mammal Study 2004; 29: 15-20. [CrossRef]

40. Guinness FE, Cluttonbrock TH, Albon SD. Factors affecting calf mortality in red deer (Cervus-Elaphus). J Anim Ecol 1978; 47: 817-832. [CrossRef]

41. Clutton-Brock TH, Guinness FE, Albon SD. The costs of reproduction to red deer hinds J Anim Ecol 1983; 52: 367-383. [CrossRef] 